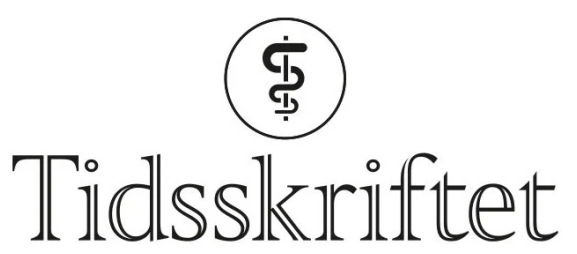

DEN NORSKE LEGEFORENING

\title{
Rettsmedisin for ikke-medisinere
}

\author{
ANMELDELSER
}

CHRISTIAN LYCKE ELLINGSEN

Stavanger universitetssjukehus

Avdeling for patologi

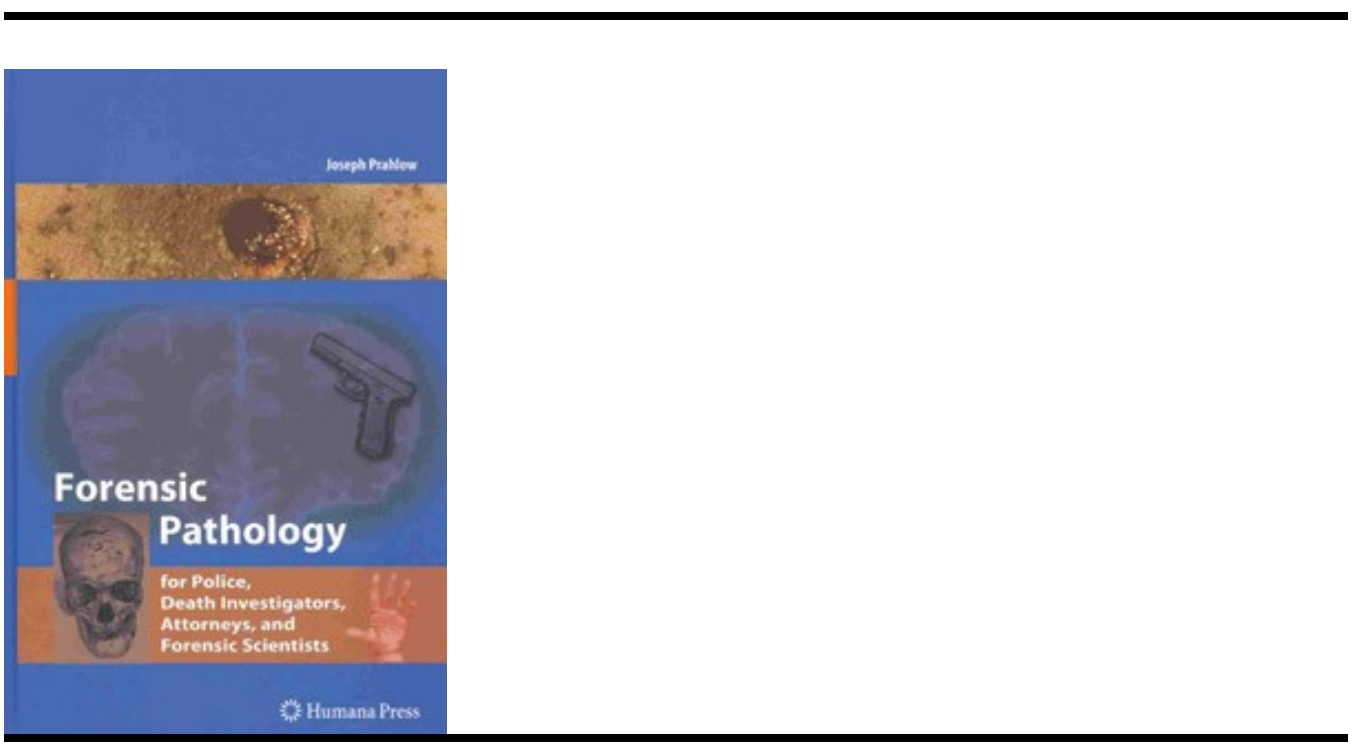

Prahlow, Joseph

Forensic pathology for police, death investigators, attorneys, and forensic scientists

632 s, tab, ill. Secaucus, NJ: Humana Press, 2010. Pris USD 199

ISBN 978-1-58829-975-8

Rettsmedisin befinner seg i grenselandet mellom biomedisin og jus eller politifag. Det må fra begge sider være et visst overlapp av kunnskap; de medisinsk sakkyndige må forstå hvordan politi og rettsvesen fungerer, og politifolk og jurister må på samme måte vite litt om hvordan rettsmedisinere utøver sitt yrke. Denne boken skal være en innføring i rettspatologi for ikke-medisinere. Dessverre synes jeg ikke den er helt vellykket.

Boken er tredelt: Først er det en introduksjon til rettsmedisin som fag, i tillegg til en innføring i anatomi og fysiologi. Den neste hoveddelen er om arbeidsmåter og -oppgaver i rettspatologi (sakkyndig likundersøkelse, identifisering og dødstidspunktsbestemmelse). Den tredje delen, som utgjør omtrent to tredeler, er en systematisk gjennomgang av de 
ulike gruppene av dødsårsaker (naturlig død, stump vold, skuddskader osv.). Denne delen avslutter man med et ganske pussig «Diverse»-kapittel med de emnene som ikke passer inn andre steder, alfabetisk ordnet: aircraft crashes, allergic reactions, animal attacks osv.

Forfatteren forsøker å være systematisk og pedagogisk; hvert kapittel starter med et kort sammendrag og noen stikkord og avsluttes med henvisning til aktuelle bilder på medfølgende CD-ROM og et utvalg referanser, som stort sett er relevante og oppdaterte. Illustrasjonene er i svart-hvitt, mørke og med dårlig kontrast. Ikke alle bildene er like informative. CD-ROM-en med fargebilder er ikke helt komplett, men alle bildene kan også lastes ned fra forlagets nettsider. Det er overraskende at bildematerialet ikke er bedre gjennomarbeidet; noen av bildene er så små at detaljene knapt er synlige, mens andre tar unødvendig stor plass. Jeg synes også at detaljeringsgraden i teksten varierer svært. For noen emner går forfatteren langt mer i dybden enn det som er hensiktsmessig for målgruppen, og på veien dit kan han hoppe over forklaringer som vil være nødvendige for en ikke-medisiner. I enkelte avsnitt er det også unødvendig mye medisinsk fagterminologi.

Det handler kun om den postmortale rettsmedisinen, og dette gjenspeiler vel den amerikanske organiseringen av faget. Norske politifolk og jurister som arbeider med personfarlig kriminalitet, har minst like stort behov for å vite noe om klinisk rettsmedisin, dvs. undersøkelse av levende personer. Rettsgenetikk er knapt nevnt, og det står kun en side om seksualrelaterte skader, omtalt i svært generelle ordelag.

Jeg mener at det finnes klart bedre bøker dersom politi og jurister i Norge ønsker seg en innføring i rettsmedisin. Den mest brukte norske er Lcerebok $i$ rettsmedisin (1). Den nyere danskspråklige Retsmedicin: nordisk lcerebog er også et godt valg (므).

\section{LITTERATUR}

1. Rognum TO, red. Lærebok i rettsmedisin. Oslo: Gyldendal Akademisk, 2001.

2. Thomsen JL, red. Retsmedicin: nordisk lærebog. 2. utg. København: FADL’s Forlag, 2008.

Publisert: 21. oktober 2010. Tidsskr Nor Legeforen. DOI:10.4045/tidsskr.10.0804

(C) Tidsskrift for Den norske legeforening 2023. Lastet ned fra tidsskriftet.no 26. april 2023. 